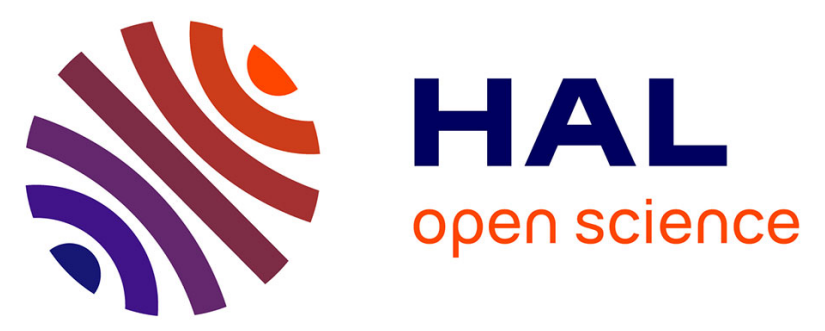

\title{
Assessing the thermal regime of poorly monitored reservoirs with a combined satellite and three-dimensional modeling approach
}

Najwa Sharaf, Bruno J. Lemaire, Ali Fadel, Kamal Slim, Vinçon-Leite Brigitte

\section{- To cite this version:}

Najwa Sharaf, Bruno J. Lemaire, Ali Fadel, Kamal Slim, Vinçon-Leite Brigitte. Assessing the thermal regime of poorly monitored reservoirs with a combined satellite and three-dimensional modeling approach. Inland Waters, 2021, 11 (3), pp.302-314. 10.1080/20442041.2021.1913937 . hal-03408367

\section{HAL Id: hal-03408367 \\ https://hal.science/hal-03408367}

Submitted on 22 Nov 2021

HAL is a multi-disciplinary open access archive for the deposit and dissemination of scientific research documents, whether they are published or not. The documents may come from teaching and research institutions in France or abroad, or from public or private research centers.
L'archive ouverte pluridisciplinaire $\mathbf{H A L}$, est destinée au dépôt et à la diffusion de documents scientifiques de niveau recherche, publiés ou non, émanant des établissements d'enseignement et de recherche français ou étrangers, des laboratoires publics ou privés. 


\title{
Assessing the thermal regime of poorly monitored reservoirs with a combined satellite and three-dimensional modelling approach
}

\author{
Najwa Sharaf ${ }^{\mathrm{a}, \mathrm{b},{ }^{*}}$, Bruno J. Lemaire ${ }^{\mathrm{b}, \mathrm{c},+}$, Ali Fadel ${ }^{\mathrm{a}}$, Kamal Slim ${ }^{\mathrm{d}}$, Brigitte Vinçon-Leite ${ }^{\mathrm{b}}$ \\ ${ }^{a}$ National Center for Remote Sensing, National Council for Scientific Research (CNRS), P.O. Box 11-8281, Riad \\ El Solh, 11072260 Beirut, Lebanon \\ ${ }^{b}$ LEESU, Ecole des Ponts ParisTech, Univ Paris Est Créteil, Marne-la-Vallée, France \\ 'Université Paris-Saclay, AgroParisTech, Paris, France \\ ${ }^{\mathrm{d}}$ Laboratory of Microorganisms and Food Irradiation, Lebanese Atomic Energy Commission, National Council for \\ Scientific Research (CNRS), P.O. Box 11-8281, Riad El Solh, 11072260 Beirut, Lebanon \\ * Corresponding author at : Ecole des Ponts ParisTech, Champs-sur-Marne, France \\ E-Mail: najwa.sharaf@enpc.fr \\ + currently at Université Paris-Saclay, INRAE, Hydrosystèmes Continentaux Anthropisés - Ressources, Risques, \\ Restauration, 92761, Antony, France.
}

\begin{abstract}
The thermal regime of lakes and reservoirs is a major driver of their functioning. However, water temperature measurements are scarce and time-series are frequently interrupted by missing data in many lakes and reservoirs. The aim of this paper is to assess whether satellite imagery combined with three-dimensional (3D) modelling can overcome this limitation. We assessed the performance of a 3D model (Delft3D-Flow) and compared simulated temperature to satellite data on a reservoir in a semi-arid region, Karaoun reservoir, Lebanon.

Surface temperatures were retrieved from Landsat 8 , atmospherically corrected using a single channel algorithm and adjusted with in situ measurements as a proxy of bulk temperatures. With very limited calibration, the model reproduced water level fluctuations, water temperature, stratification and mixing, with low discrepancies from measurements. Satellite temperatures were found to be in good agreement with observations and simulations. Satellite temperature distributions across the reservoir exhibited low spatial heterogeneity. The 3D model partly reproduced this spatial distribution of surface temperature but generally showed good ability to simulate the thermal regime of the reservoir with a limited data set for initial conditions and for hydrological and meteorological forcing, and with limited calibration. For validating 3D hydrodynamic models, satellite temperatures constitute a valuable source of data which are complementary to point measurements. Coupling satellite imagery and modelling can improve operational surveys of poorly monitored lakes and reservoirs, and enhance knowledge of their thermal functioning.
\end{abstract}

Keywords: hydrodynamic model, water surface temperature, thermal remote sensing, Landsat 8, Karaoun Reservoir, Delft3D. 


\section{Introduction}

The deterioration of water quality in lakes and reservoirs has resulted in eutrophication and health risks for drinking water supplies. Water scarcity is also expected to be a major concern by the middle of the 21st century (Makarigakis and Jimenez-Cisneros, 2019), increasing current problems in semi-arid regions. Adaptation requires the understanding of ecosystem functioning, which is influenced by water temperature and thermal stratification, which acts as a barrier controlling the distribution of heat, nutrients and dissolved substances in the water column (Yang et al. 2016; Liu et al. 2019). The factors influence the chemical (Delpla et al. 2009) and biological properties (Sharma et al. 2007) of lakes and reservoirs, notably the spatial distribution of harmful algal blooms (Cyr 2017). Water surface temperature is an important indicator of lake thermal regime, and of its response to climate change (Adrian et al. 2009). The interest in water surface temperature arises from its sensitivity and responsiveness to meteorological forcing (Livingstone et al. 2001).

During the last decade, satellite imagery has provided complementary data to in situ monitoring of lakes and reservoirs. Satellite remote sensing gives access to optically active constituents that reflect bio-physical properties, with a far larger spatial coverage than in situ monitoring. It can provide maps of the spatial heterogeneity of the surface layer, namely the first few micrometers for water temperature (skin temperature), while in situ surface temperatures (bulk temperatures) are typically recorded at a few tens of centimeters below the water surface (Prats et al. 2018). Cloud cover is one of the main limitations.

Satellites with coarse spatial resolutions (e.g., $250 \mathrm{~m}-1 \mathrm{~km}$ for MODIS) have long been applied to large lakes to retrieve surface temperature (Reinart and Reinhold, 2008; Crosman and Horel, 2009). High resolution multispectral sensors with decades of remote sensing images (e.g. Landsat, $100 \mathrm{~m}$ ) have helped to extend these techniques to medium sized lakes and reservoirs and to subbasins of large lakes at finer spatial coverage (Watanabe et al. 2018; Deutsch and Alameddine, 2018; Sharaf et al. 2019a).

To understand the thermal regime of lakes and reservoirs, water temperature in deeper layers is also required. Three-dimensional modelling provides a means to examine hydrodynamic and ecological processes taking place over long periods of time at high resolution throughout the lake volume (Soulignac et al. 2019).

Coupling satellite remote sensing and hydrodynamic modelling constitutes a very promising approach for better understanding of lake and reservoir hydrodynamics. It has been applied to lakes far less than in coastal and ocean systems. It was applied in Lake Geneva for understanding phytoplankton distributions in the epilimnion (Soulignac et al. 2018), and in a large tropical hydroelectric reservoir, Intumbiara Reservoir, Brazil, for investigating the impacts of winter cold front passages on the heat balance and diurnal mixed layer dynamics (Curtarelli et al. 2014). It has also been used for validating simulated surface temperature in a very large and shallow lake, Lake Poyang, China (Li et al. 2017) and in a small lake, Lake Rotoehu, New Zealand (Allan et al. 2016). Satellite images have been also assimilated in 3D hydrodynamic models of large lakes, for example Lake Geneva (Baracchini et al. 2020) and Lake Erie (Ye et al. 2020) as well as medium-sized reservoirs, for example Eagle Creek reservoir (Javaheri et al. 2016).

In this context, the aim of this paper is to assess whether satellite imagery combined with $3 \mathrm{D}$ modelling can enhance the understanding of the thermal regime of poorly monitored reservoirs. For this purpose, the performance of a 3D model was first assessed and the simulated temperature 
validated by comparison to satellite data, on a reservoir in a semi-arid region, Karaoun reservoir, Lebanon.

\section{Materials and methods}

\section{Study site}

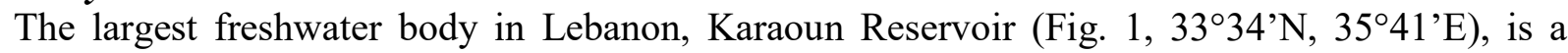
relatively deep, monomictic, eutrophic lake and is one of the few that are regularly monitored in the Middle East. It is located in the Bekaa valley in Lebanon. It has a surface area of $12 \mathrm{~km}^{2}$ at full capacity ( $859 \mathrm{~m}$ above sea level) with a maximum depth of $60 \mathrm{~m}$ and a mean depth of $19 \mathrm{~m}$ (Fadel et al. 2014). It has large fluctuations in the water level ( $\sim 25 \mathrm{~m}$ in a year), mainly due to the withdrawal at $11 \mathrm{~m}$ elevation above the lake bottom. Karaoun Reservoir is refilled annually, in autumn and winter, by the inflow from the only tributary, the Litani River. During the dry season, the reservoir stratifies continuously between May and August. The thermal stratification usually breaks down in September as a result of vertical mixing due to air cooling and higher inflows.

Karaoun Reservoir is an important resource for hydropower and irrigation, and may be used in the future for drinking water production. During the last decade, regular in situ monitoring revealed declining water quality, including persistent toxic cyanobacterial blooms, mainly Microcystis aeruginosa and Chrysosporum ovalisporum (Fadel et al. 2015; Fadel and Slim 2018, Fadel et al. 2019). These blooms currently limit water usage to hydropower production. Monitoring and understanding the reservoir thermal regime and the resulting ecological status will help define adequate management strategies.
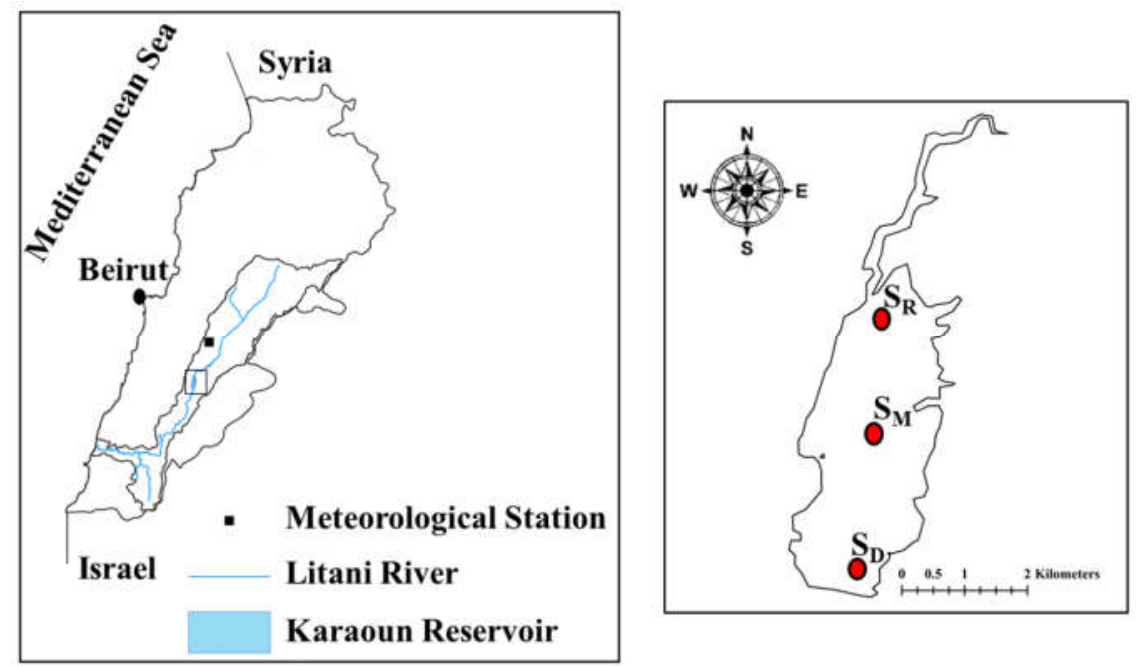

Figure 1: Karaoun Reservoir location (within box, left-hand side) and contour at full capacity, with monitoring sites $S_{D}$ near the dam, $S_{M}$ in the middle of the reservoir and $S_{R}$ near the Litani River inlet (right-hand side).

\section{In situ data}

The performance of the 3D model Delft3D-Flow to simulate the thermal regime was first investigated with in situ measurements. In parallel, water surface temperatures were retrieved from Band 10 of the thermal infrared sensor onboard Landsat 8 and adjusted with in situ measurements. 
The spatial distribution and time evolution of surface temperature observed by the satellite and simulated by the model were compared.

Subsurface ( $0.2 \mathrm{~m}$ depth) water temperature measurements acquired in 2017 were used to validate values obtained from remote sensing. For the modelling, in addition to water temperature measurements, input data included water level, inflow rate and withdrawal (Fig. 2) and meteorological data (Fig. 3) collected in 2012 and 2017. Daily inflow, withdrawal and water level measurements were collected from the Litani River Authority (Fig. 2).

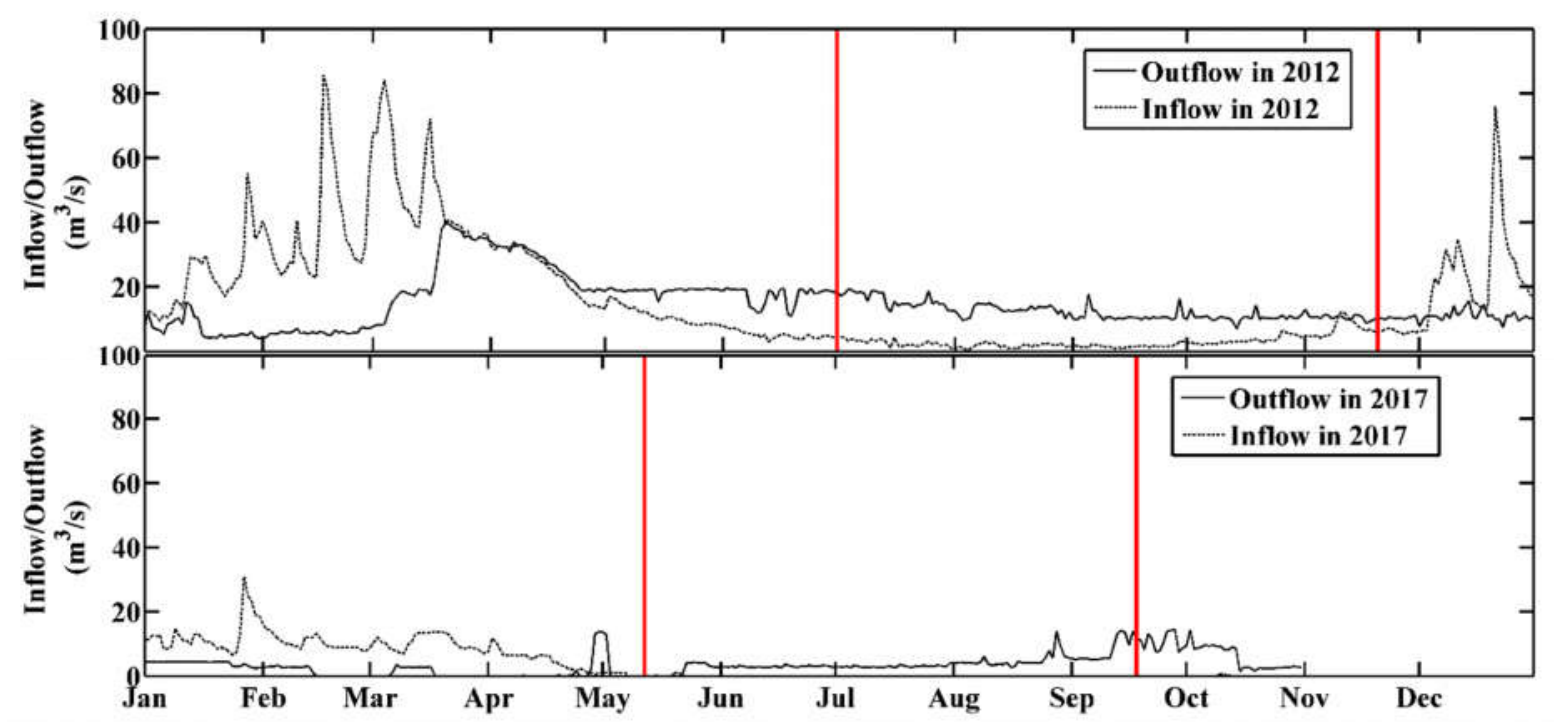

Figure 2: Inflow and outflow rates at Karaoun Reservoir in 2012 and 2017. Data were available only until October in 2017. Period between red lines indicates the simulation periods.
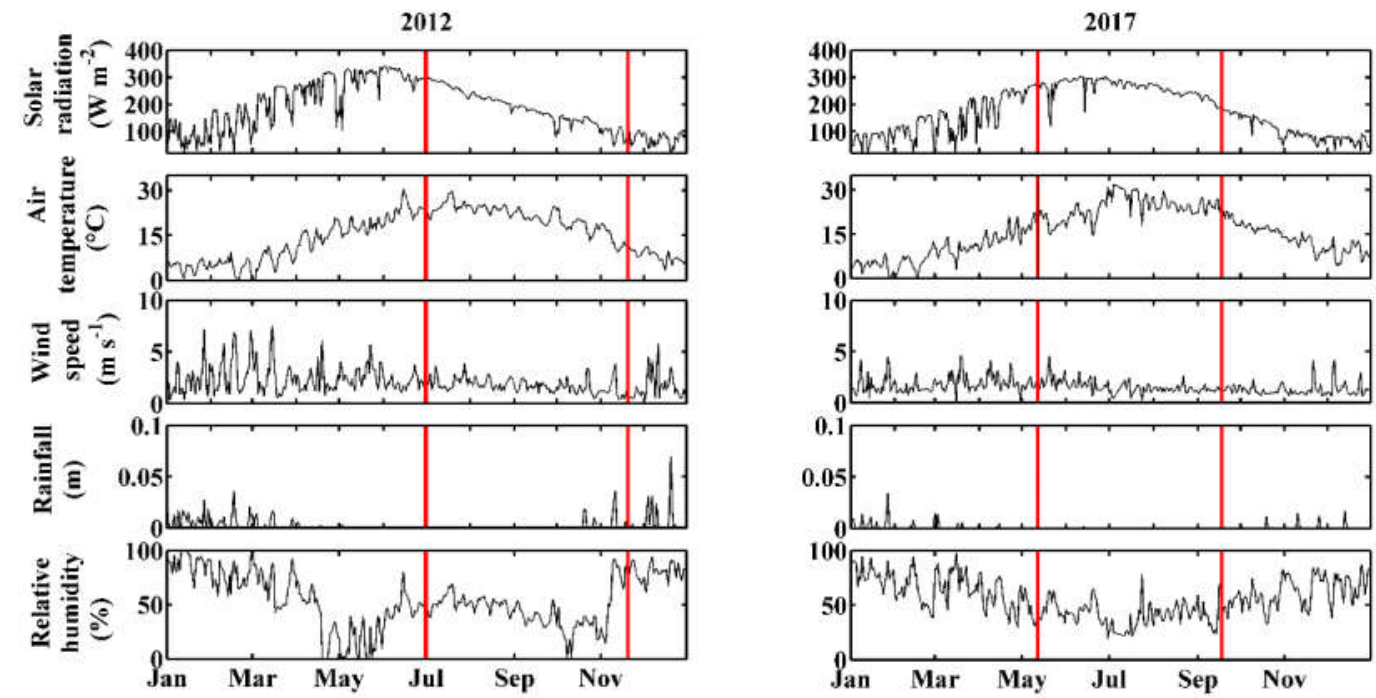

Figure 3: Meteorological conditions in 2012 and 2017: daily solar radiation, air temperature, wind speed, relative humidity and precipitation. Red lines indicate simulation periods. 
Vertical profiles of water temperature were recorded with a thermistor chain (Starmon sensors in 2012 , lost and replaced by HOBO sensors in 2017 , with 0.05 and $0.5^{\circ} \mathrm{C}$ accuracy respectively) at 3 locations in the reservoir, $S_{D}$ near the dam, $S_{M}$ in the middle and $S_{R}$ near the Litani River inlet (Fig. 1). Data were acquired hourly at different depths; at 1, 4, 7, 10, 13 and $16 \mathrm{~m}$ at $\mathrm{S}_{\mathrm{D}}$ in 2012 , at $0.2,5,10$ and $15 \mathrm{~m}$ at $\mathrm{S}_{\mathrm{R}}$ and $\mathrm{S}_{\mathrm{M}}$ and at $0.2 \mathrm{~m}$ at $\mathrm{S}_{\mathrm{D}}$ in 2017 (Fig. 1). The deeper sensors were progressively removed while the water level decreased, in order to avoid contact with the reservoir bottom. Transparency was measured monthly using a Secchi disk, each time coinciding with a satellite overpass in 2017.

Meteorological data (solar radiation, wind speed and direction, relative humidity, air temperature and rainfall) at the Tal Amara station located in the Bekaa valley, $40 \mathrm{~km}$ north of Karaoun Reservoir and at a slightly higher altitude of $905 \mathrm{~m}$, were provided by the Lebanese Agricultural Research Institute (Fig. 1). These were used at a daily time step in 2012 and at an hourly time step in 2017 (Fig. 3). The cloud cover, which is often negligible during the summer season in Karaoun catchment, was set to zero.

\section{Model description and configuration}

Delft3D-Flow, version 4.01.01.rc.03 (Deltares 2013), was used to simulate the hydrodynamics of Karaoun Reservoir. Delft3D-Flow has been proven to simulate well the thermal regime, the hydrodynamics and the response to climate change of large lakes (Wahl and Peeters, 2014), shallow lakes (Soulignac et al. 2017) and reservoirs (Chanudet et al. 2012). The model was configured to run in hydrostatic mode. The model solves the Reynolds-averaged Navier-Stokes equations for an incompressible fluid with the Boussinesq approximation. The unsteady shallow water equations include those for continuity, horizontal momentum and heat transport.

The bathymetry of Karaoun Reservoir was constructed with water contours derived from satellite images and the water level measurements provided by the reservoir manager. Water contours were extracted from several Landsat images at dates with different water levels (at the maximum level, and $13.5 \mathrm{~m}$ and $17.44 \mathrm{~m}$ below the maximum level) (Supplementary material).

The horizontal surface of the Karaoun Reservoir was meshed with 3177 Cartesian grid cells of 50 $\mathrm{m} \times 50 \mathrm{~m}$ using the Z-grid model. The layer thickness was $0.2 \mathrm{~m}$, except for the 15 lower layers with a coarser resolution of $3 \mathrm{~m}$ in order to limit computation time. Active mesh layers changed with the water level according to the bathymetry of the reservoir.

The model was forced with the solar radiation, wind speed and direction, rainfall, air temperature and humidity, and with the inflow and outflow rates described previously. The depth-averaged water temperature measured at $\mathrm{S}_{\mathrm{R}}$ was used as inflow temperature.

The ocean heat flux module was used to calculate a surface heat budget. The latent and sensible heat fluxes due to forced and free convection are parameterized with the values of the Stanton and Dalton numbers recommended by the model authors (Deltares 2013). The computational time step was set to $1 \mathrm{~min}$ and the Courant-Friedrichs-Lewy condition was respected, with a maximum value of the Courant number (horizontal velocity times time step divided by horizontal grid size) of 6 . The vertical eddy viscosity and diffusivity were calculated using the $k-\varepsilon$ turbulence model where $k$ is the turbulent kinetic energy and $\varepsilon$ the energy dissipation. In the horizontal and vertical directions, the eddy viscosities are defined by: 


$$
\begin{aligned}
& v_{H}=v_{V}+v_{H}^{\text {back }} \\
& v_{V}=v_{m o l}+v_{3 D}
\end{aligned}
$$

where $v_{H}$ is the horizontal eddy viscosity $\left(\mathrm{m}^{2} \mathrm{~s}^{-1}\right), v_{V}$ the vertical eddy viscosity, $v_{H}^{\text {back }}$ the background horizontal eddy viscosity, $v_{m o l}$ the kinematic viscosity and $v_{3 D}$ the eddy viscosity computed by the $\mathrm{k}-\varepsilon$ turbulence closure model. In the horizontal and vertical directions, the eddy diffusivities are respectively defined by:

$$
\begin{aligned}
& D_{H}=D_{V}+D_{H}^{\text {back }} \\
& D_{V}=v_{m o l} / \sigma_{m o l}+D_{3 D}
\end{aligned}
$$

With $D_{H}$ the horizontal eddy diffusivity $\left(\mathrm{m}^{2} \mathrm{~s}^{-1}\right), D_{V}$ the vertical eddy diffusivity, $D_{H}^{\text {back }}$ the background horizontal eddy diffusivity, $\sigma_{m o l}$ the Prandtl-Schmidt number (0.7) and $D_{3 D}$ the eddy diffusivity computed by the turbulence model.

Background terms $v_{H}^{\text {back }}$ and $D_{H}^{\text {back }}$ were first computed by the 2D horizontal large eddy simulation module embedded in Delft3D as the averages of the 2D eddy viscosity and diffusivity over the whole simulation domain and over the calibration period $\left(0.1 \mathrm{~m}^{2} \mathrm{~s}^{-1}\right.$ for both). They were then used as uniform background values for 3D simulations.

The wind drag coefficient was assigned a value of 0.0015 . This value is close to the value adopted in most modelling studies, e.g. 0.0013 and 0.0019 in the 1D model Simstrat for Lake Zurich and Lake Constance (Peeters et al. 2002; Wahl and Peeters, 2014), 0.0018 in a 1D model for Lake Bourget (Vinçon-Leite et al., 2014), 0.0015 in Delft3D-Flow for shallow Lake Créteil (Soulignac et al. 2017) and is consistent with the values expected in the wind speed range 1-5 $\mathrm{m} \mathrm{s}^{-1}$ (Wüest and Lorke, 2003). The bottom roughness was computed with the Chézy formulation, with the default parameter value of $65 \mathrm{~m}^{0.5} \mathrm{~s}^{-1}$; the vertical wall roughness was neglected.

Amongst the model parameters, only the Secchi depth was adjusted, focusing on epilimnion temperatures from satellite images. The calibrated values, $2.5 \mathrm{~m}$ in 2012 and $1.7 \mathrm{~m}$ in 2017 are within the range of measured values which ranged between 1.5 and $3 \mathrm{~m}$ in $2012(n=12)$ and between 1 and $1.7 \mathrm{~m}$ in $2017(n=14)$.

\section{Model simulations}

Simulations started on July 12012 and May 12 2017, the dates of the first measuring campaigns, and ended on November 212012 and September 18 2017, the dates of the last available measurements. The model was run with the following initial conditions: the measured water level water, current velocities set to zero and horizontally uniform but vertically stratified water temperature. To do so, temperature profiles measured at the first day of each simulation were averaged depth by depth over the monitoring sites. Since temperature was not measured in the deepest part of the reservoir, the value measured at greatest depth was used to complete this initial profile down to the bottom of the reservoir.

The model performance was assessed by comparing measurements and model simulations of water level and of water temperature profiles at the three monitoring sites. Temperatures simulated at cell centers at fixed elevations were linearly interpolated at the elevations of buoy sensors which decreased during the reservoir drawdown. The Root Mean Square Error (RMSE), the Mean 
Absolute Percent Error (MAPE) and the Mean Absolute Error (MAE) were used as indicators. They were calculated for each depth over the simulation periods and can be defined as:

$$
\begin{aligned}
& R M S E=\sqrt{\frac{\sum_{i=1}^{n}\left(T_{\text {sim }, i} T_{\text {In situ }, i}\right)^{2}}{n}} \\
& \text { MAPE }=\frac{100}{n} \sum_{i=1}^{n}\left|\frac{T_{\text {sim }, i}}{T_{\text {In situ }, i}}\right| \\
& M A E=\frac{1}{n} \sum_{i=1}^{n}\left|T_{\text {sim }, i} \quad T_{\text {In situ }, i}\right|
\end{aligned}
$$

where $T_{\text {sim }}$ and $T_{\text {In situ }}$ are vectors of simulated and measured water temperatures.

\section{Satellite thermal data and successive corrections}

As described by Sharaf et al. (2019b), Band 10 of the most recent Landsat 8 Thermal Infra-Red Sensor (TIRS) was used to retrieve the water surface temperature of Karaoun Reservoir in 2017. Nine images were acquired between April 26 and September 12017 (at 11:10 h. local time). All pixels crossing the reservoir shoreline were discarded. The images were corrected twice: as detailed below and the generalized single-channel algorithm (SC) was used for the atmospheric correction of temperatures (Jiménez-Muñoz et al. 2014), without any calibration. Following Javaheri et al. (2016), these skin temperatures were adjusted by linear regression with bulk temperatures so that satellite and model temperatures could be compared for a second validation of the model with satellite-retrieved temperatures.

The inputs of the generalized single-channel algorithm include the atmospheric water vapor content and water surface emissivity $(\varepsilon)$. The algorithm retrieves surface temperature ( $T_{\text {Satellite }}$ in $K$ ) using the following general equation:

$$
T_{\text {Satellite }}=\gamma\left(\varepsilon^{-1}\left(\Psi_{1} L_{S e n}+\Psi_{2}\right)+\Psi_{3}\right)+\delta
$$

where $\Psi_{1}, \Psi_{2}$ and $\Psi_{3}$ are functions of atmospheric transmissivity and upwelling and downwelling atmospheric radiances, and are approximated with a polynomial form of the water vapor content; $L_{S e n}$ is the at-sensor radiance; $\gamma$ and $\delta$ are two parameters dependent on at-sensor temperature. Parameter values change for each satellite sensor. To limit errors, applying the algorithm is recommended when the atmospheric water vapor content is lower than $3 \mathrm{~g} \mathrm{~cm}^{-2}$, which is the case at Karaoun Reservoir during the simulation periods. The algorithm was previously validated for Karaoun reservoir for 2016 and 2017 bulk temperature measurements, with parameter values adapted for Landsat 8 TIRS (Sharaf et al. 2019b) and water vapor content data obtained from the reanalysis dataset of the European Centre for Medium-Range Weather Forecasts (Dee et al. 2011).

We used the linear regression of bulk temperature measurements versus atmospherically-corrected satellite skin temperatures to further correct satellite images acquired in 2017. We extracted 21 water surface temperatures measured at $0.2 \mathrm{~m}$ depth at the three monitoring sites $\left(\mathrm{S}_{\mathrm{R}}, \mathrm{S}_{\mathrm{M}}\right.$ and $\left.\mathrm{S}_{\mathrm{D}}\right)$ during satellite overpasses. The corresponding atmospherically corrected satellite-retrieved temperatures were averaged over the four $30 \mathrm{~m}$ resampled Landsat 8 pixels around the monitoring site. The linear regression was also used to generate water surface temperature maps. Each map 
was compared with the map of modeled surface temperatures at the time of satellite overpass, based on the mean and the standard deviation of the spatial distribution and on anomaly maps.

\section{Results}

The model is validated in 2 steps. The first step focused on the performance of the model for simulating the evolution of both the water level and the vertical temperature profile. The second step detailed the results of the correction of satellite temperatures and the comparison of surface temperature heterogeneities in model simulations and in satellite maps.

\section{Validation of the hydrodynamic model with field measurements}

The performance of the Delft3D-Flow model was validated by comparing measurements and simulations of the water level and of the water temperature profile at the 3 monitoring sites.

\section{Water level fluctuations}

Time series of measured and simulated water levels in 2012 and 2017 are shown in Fig. 4a and b. The study periods, from 1 July 2012 to 21 November 2012 and from 12 May 2017 to 18 September 2017 , are marked by very low inflow rates from the Litani River, especially in 2017, and by considerable drawdowns in the water level, $15 \mathrm{~m}$ in 2012 and $8 \mathrm{~m}$ in 2017 (Fig. 2). The comparison between model results and measurements of water level (Fig. 4) shows that the model reproduced very well the general drawdown in the water level at the time of the study, with a MAE and a RMSE smaller than 0.2 and $0.3 \mathrm{~m}$ respectively, corresponding to less than 2\% (MAPE) of the water depth.

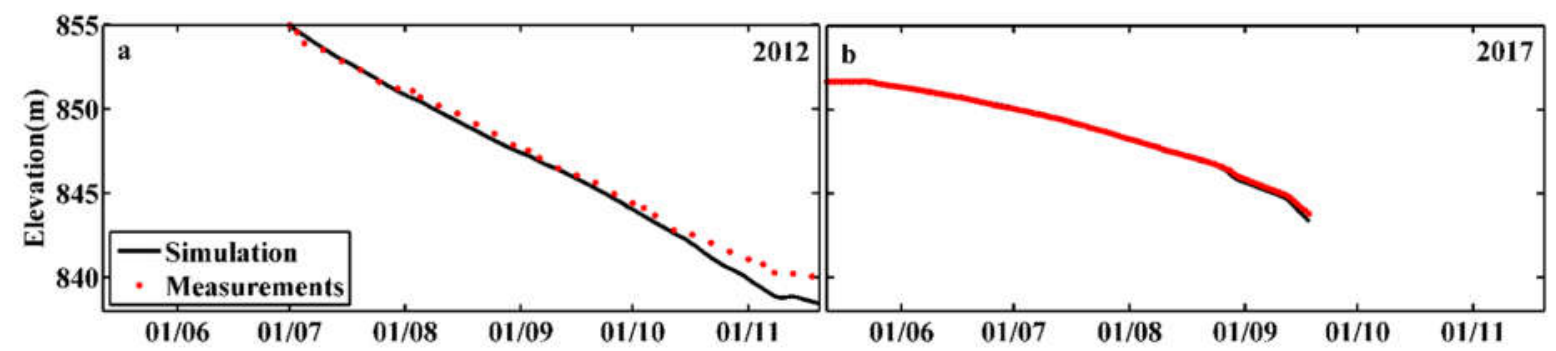

Figure 4: Daily averaged model results and measurements of the water level in (a) 2012 and (b) 2017. Date format is day/month.

\section{Water temperature vertical profiles and thermal stratification}

Simulations of water temperature in 2012 and 2017 were undertaken under thermally stratified conditions, except in October and November of 2012 when the reservoir was mixed. Fig. 5 represents simulated and measured water temperature contours for sites $S_{D}$ in 2012, and for $S_{R}$ and $\mathrm{S}_{\mathrm{M}}$ in 2017. The corresponding difference between simulated and measured water temperatures is shown in Fig. 6. A comparison in space and time is only possible at point $S_{M}$ in 2017, with measurements covering the simulation period and depths down to $15 \mathrm{~m}$. The Delft3D-Flow model predicted well the vertical profiles of water temperature, the establishment of thermal stratification, and partial and full mixings with small discrepancies. In July 2017, the model overestimated temperature in surface layers by up to $4{ }^{\circ} \mathrm{C}$ in early July but MAE is $0.5{ }^{\circ} \mathrm{C}$ over the whole simulation period (Table 1). At site $\mathrm{S}_{\mathrm{D}}$ in July 2012, the overestimation occurred both at the surface 
and at the thermocline. For both years, the MAE and the RMSE do not exceed $2^{\circ} \mathrm{C}$ at all depths at the three monitoring sites (Table 1). The relative errors (MAPE) of epilimnion temperature do not exceed $5 \%$.

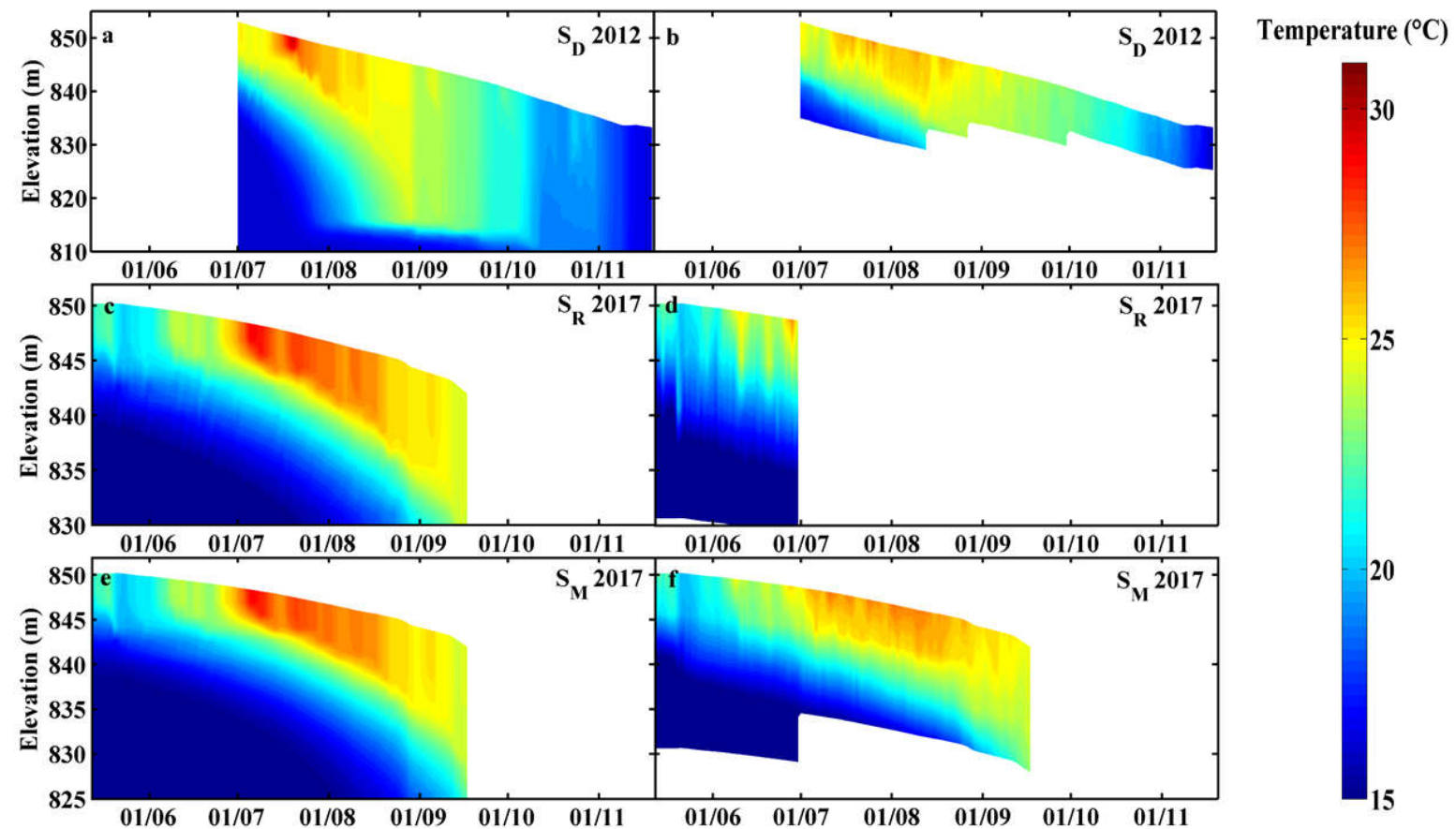

Figure 5: Daily averaged simulated (a, c, e) and measured (b, d, f) water temperature at sites $S_{D}$ in 2012 and $S_{R}$ and $S_{M}$ in 2017. Measurements at fixed depths were linearly interpolated. The jump in the maximum depth of measurements corresponds to each time the deeper sensors were removed when they approached the sediment ( $b$ and $f$ ). At each site, the lower limit of the vertical scale corresponds to the sediment. Date format is day / month.

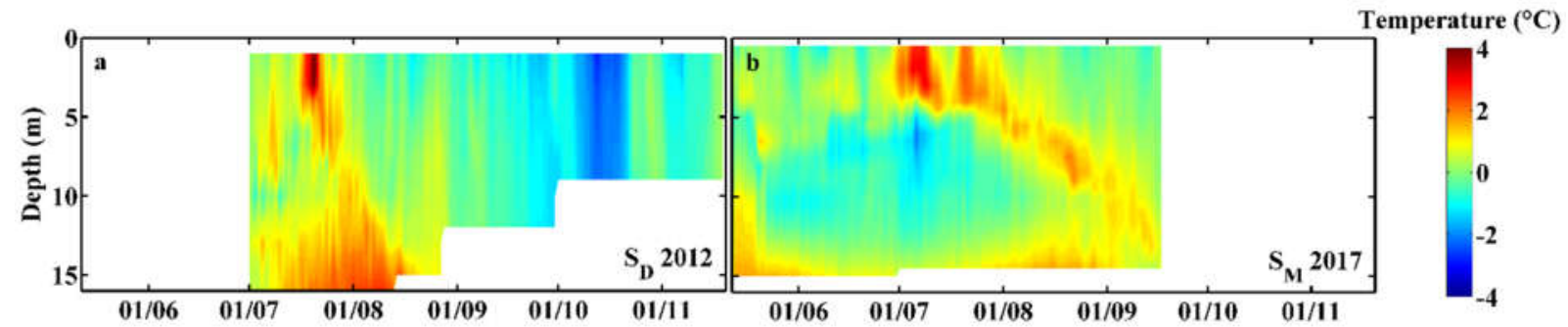

Figure 6: Differences between simulated and measured temperatures at sites (a) $S_{D}$ in 2012, and (b) $S_{M}$ in 2017. Date format is day/month. 
Table 1: Simulation performance indicators for the water temperature at the different depths at the 3 monitoring sites. The indicators were calculated with hourly values over the periods shown in row label.

\begin{tabular}{|c|c|c|c|c|c|c|c|}
\hline \multicolumn{8}{|c|}{2012} \\
\hline & Period & & $1 \mathrm{~J}$ & $21 \mathrm{~N}$ & 343 & & 1 Jul to $27 \operatorname{Aug}(n=1369)$ \\
\hline \multirow[t]{4}{*}{$\mathbf{S}_{\mathrm{D}}$} & Depth (m) & 1 & 4 & 7 & 10 & 13 & 16 \\
\hline & RMSE $\left({ }^{\circ} \mathrm{C}\right)$ & 0.9 & 0.9 & 0.6 & 0.5 & 1.0 & 1.9 \\
\hline & MAPE (\%) & 2.5 & 2.2 & 1.8 & 1.8 & 3.7 & 7.5 \\
\hline & MAE $\left({ }^{\circ} \mathbf{C}\right)$ & 0.6 & 0.5 & 0.4 & 0.4 & 0.9 & 1.7 \\
\hline \multicolumn{8}{|c|}{2017} \\
\hline & Period & & $12 \mathrm{~N}$ & to 30 & $=11^{\prime}$ & & \\
\hline \multirow[t]{5}{*}{$\mathbf{S}_{\mathbf{R}}$} & Depth (m) & 0.2 & 5 & 10 & 15 & & \\
\hline & RMSE $\left({ }^{\circ} \mathrm{C}\right)$ & 0.7 & 0.7 & 1.2 & 0.9 & & \\
\hline & MAPE (\%) & 2.3 & 2.2 & 5.0 & 5.1 & & \\
\hline & MAE $\left({ }^{\circ} \mathbf{C}\right)$ & 0.6 & 0.5 & 1.0 & 0.7 & & \\
\hline & Period & \multicolumn{5}{|c|}{12 May to $18 \operatorname{Sep}(n=3097)$} & \\
\hline \multirow[t]{4}{*}{$\mathbf{S}_{\mathbf{M}}$} & Depth (m) & 0.2 & 5 & 10 & 15 & & \\
\hline & RMSE $\left({ }^{\circ} \mathrm{C}\right)$ & 0.8 & 0.5 & 0.6 & 1.2 & & \\
\hline & MAPE (\%) & 1.9 & 1.5 & 2.5 & 5.0 & & \\
\hline & MAE $\left({ }^{\circ} \mathrm{C}\right)$ & 0.5 & 0.3 & 0.6 & 1.1 & & \\
\hline \multirow[t]{4}{*}{$\mathbf{S}_{\mathbf{D}}$} & Depth (m) & 0.2 & & & & & \\
\hline & RMSE $\left({ }^{\circ} \mathrm{C}\right)$ & 1.1 & & & & & \\
\hline & MAPE (\%) & 2.8 & & & & & \\
\hline & MAE $\left({ }^{\circ} \mathbf{C}\right)$ & 0.7 & & & & & \\
\hline
\end{tabular}

Thermal stratification was established between June and September of 2012 and 2017. It persisted till the end of September with a thermocline established between 5 and $15 \mathrm{~m}$. The maximum temperature difference between the subsurface and the top of the hypolimnion was of $10{ }^{\circ} \mathrm{C}$ in 2012 and $16^{\circ} \mathrm{C}$ in 2017 . The model represented well this behavior, including the maximum temperature difference of $11.9^{\circ} \mathrm{C}$ in 2012 and $14.7^{\circ} \mathrm{C}$ in 2017 . Based on these results, the model is considered to have a satisfactory performance and simulated surface temperatures can be further compared to satellite images.

\section{Validation of the hydrodynamic model with satellite images}

Efficiency of the correction of satellite skin temperature with measured sub-surface temperature After atmospheric correction, satellite surface temperatures were compared to measured temperatures at $0.2 \mathrm{~m}$ depth at the three monitoring points and on eight dates. The statistical measurements indicate a good performance of the atmospheric correction algorithm with $r=0.97$ and $\mathrm{RMSE}=0.6{ }^{\circ} \mathrm{C}(n=21)$. The water vapor content remained in the range where the algorithm performs best, below $3 \mathrm{~g} \mathrm{~cm}^{-2}$. The following linear regression equation was derived between satellite and in situ sub-surface temperatures.

$$
T_{\text {situ }}=0.793 T_{\text {Satellite }}+4.95
$$

After the correction of skin satellite temperatures with this linear regression, they were used as a proxy of surface bulk temperatures for comparison for the hydrodynamic model. The temporal evolution of these corrected satellite temperatures fits well with measured temperatures, as shown in Fig. 7a-c. Considerable discrepancies between satellite values and measurements only occurred on $16 / 08 / 2017$, by around $2{ }^{\circ} \mathrm{C}$. 


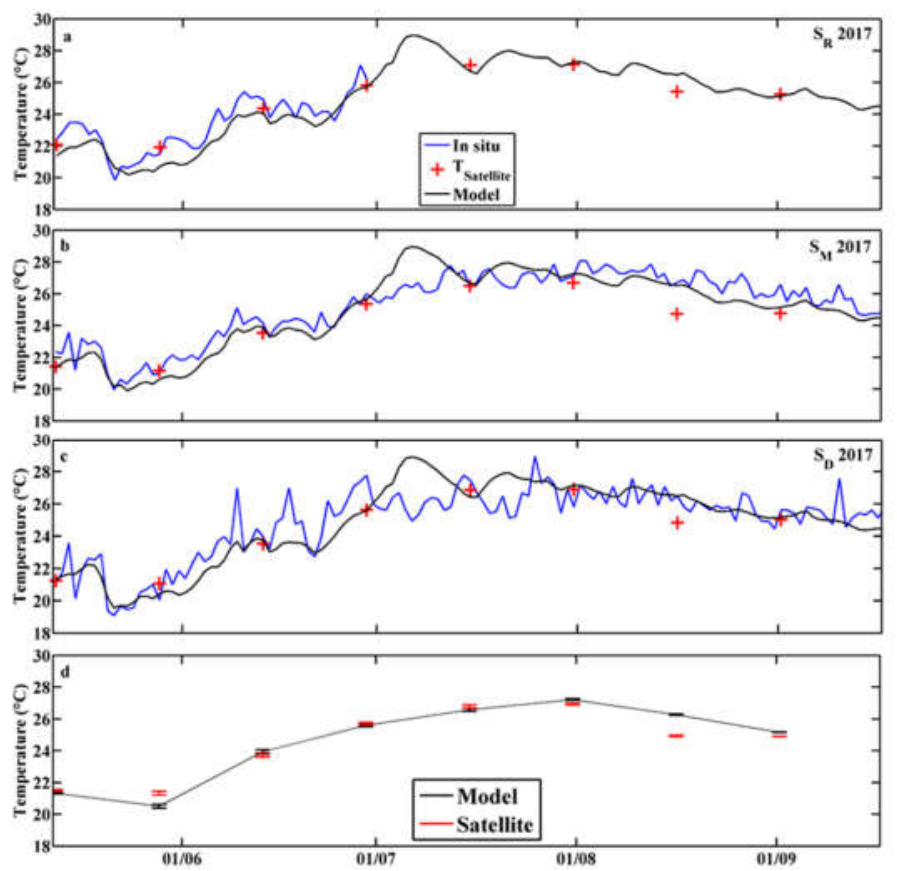

Figure 7: Surface temperature derived from Landsat 8, in situ measurements and the Delft3D-Flow model for sites (a) $\mathrm{S}_{\mathrm{R}}$, (b) $\mathrm{S}_{M}$ and (c) SD on dates of Landsat 8 overpasses in 2017 at Karaoun Reservoir. (d) Means (dot) and standard deviations (SD, bar) of model simulations and of satellite temperatures, after atmospheric correction and adjustment with measurements. Date format is day / month.

Analysis of temperature at the reservoir surface in satellite and model maps

Surface temperature maps were derived from corrected satellite data and from model simulations in 2017 on dates of Landsat 8 overpasses (Fig. 8, Fig. 9). The surface mean and the standard deviation of temperature for the model and satellite maps for each overpass are also shown in Fig. $7 \mathrm{~d}$. Satellite maps showed the expected seasonal variations in water temperature. Surface temperature increased gradually during the summer season with highest values occurring in July (Fig. 8 and 7d). The same evolution was also observed in the maps of simulated surface temperatures (Fig. 9 and $7 d$ ).

In order to analyze the surface temperature patterns in 2017, anomaly maps were plotted based, for each map, on the differences of each pixel temperature from the surface average as temperature reference (Fig. 10). For each satellite overpass, the anomaly maps are presented for model simulations and for corrected satellite temperature. Satellite maps show small spatial heterogeneities, close to the sensor resolution. The standard deviation of temperature is narrower in the model than in the satellite images, typically by around one-third (Fig. 7d). Warm waters are mostly located in the littoral zones. An east-west gradient appears on 12/05, 13/06 and 31/07, a south-north gradient on 28/05,15/07 and 16/08, and warmer littoral zones around the lake on 29/06 and 01/09/2017. Model maps exhibit a south-north gradient from 28/05 to 31/07. A slight WestEast gradient may be seen on 13/06, and from 31/07 to 01/09, in a direction opposite to that on satellite maps for the 2 former dates. 


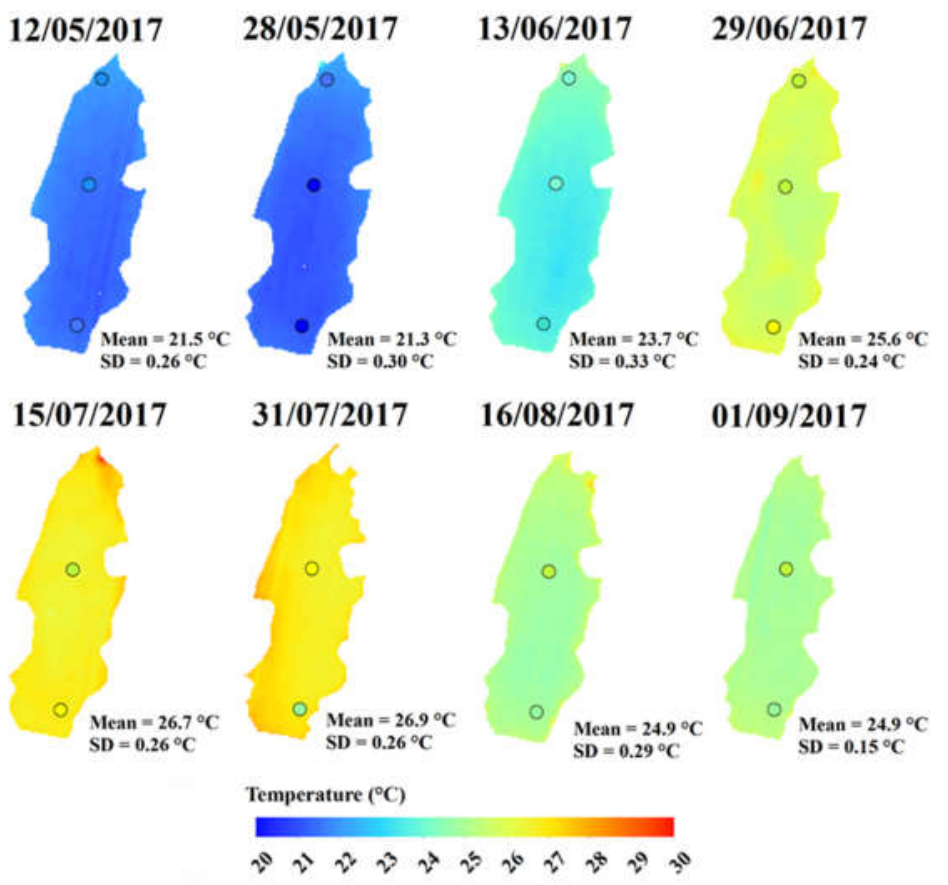

Figure 8: Landsat 8 maps of water surface temperature in 2017, after atmospheric correction and adjustment with bulk measurements. Markers correspond to in situ measurements at sites $\mathrm{S}_{\mathrm{R}}, \mathrm{S}_{\mathrm{M}}$ and $\mathrm{S}_{\mathrm{D}}$. The colors of the markers correspond to the temperature values shown in the legend. The mean and standard deviation (SD) of surface temperature at the reservoir are indicated for each map. Date format is day/month.

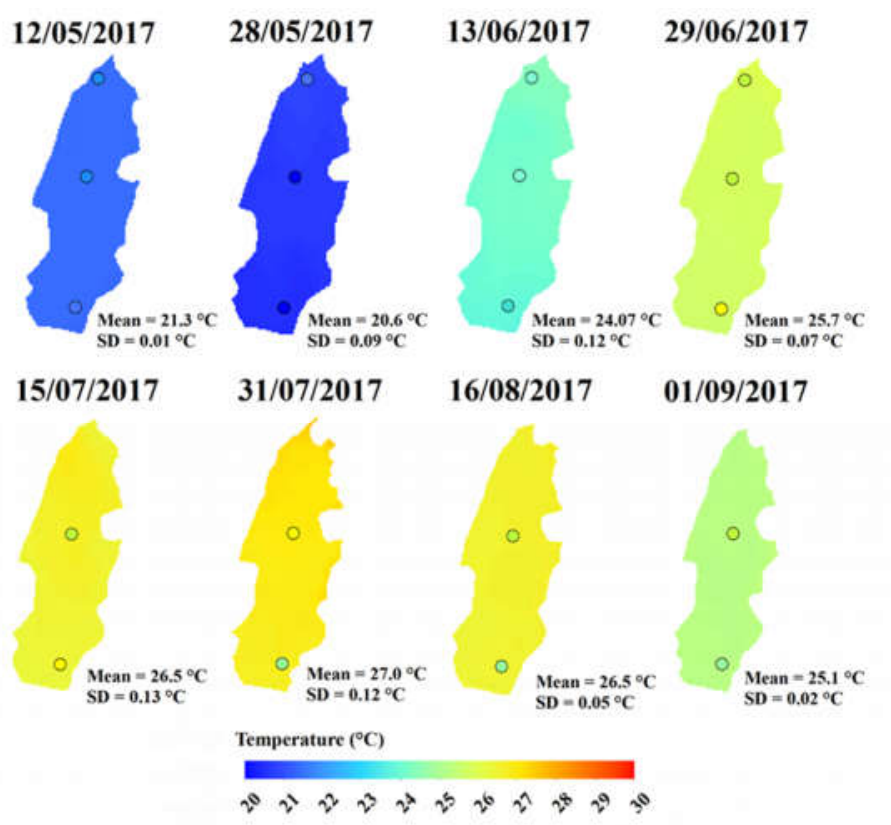

Figure 9: Water surface temperature maps generated from model simulations in 2017 on dates of Landsat 8 overpasses. Markers correspond to in situ measurements at sites $\mathrm{S}_{\mathrm{R}}, \mathrm{S}_{\mathrm{M}}$ and $\mathrm{S}_{\mathrm{D}}$. The colors of the markers correspond to the temperature values shown in the legend. Date format is day/month. 

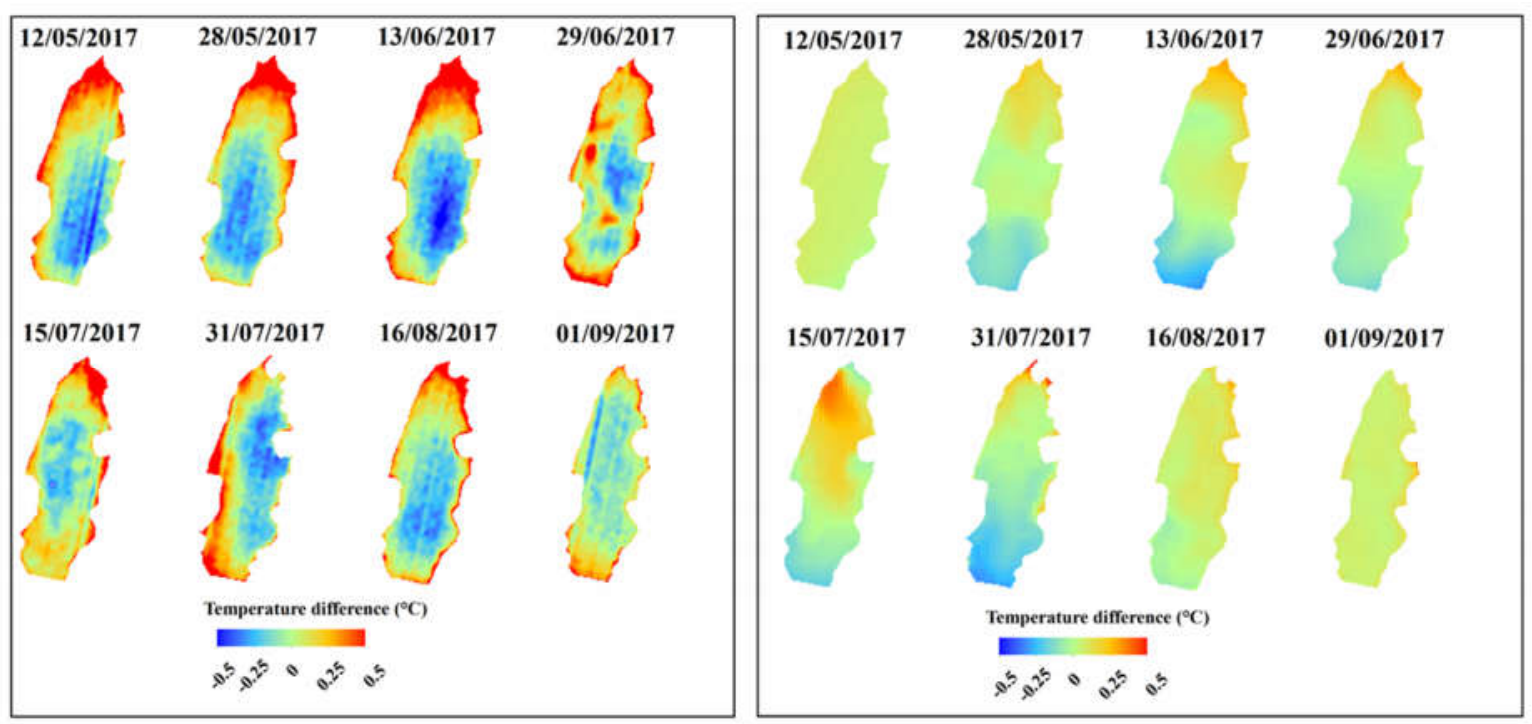

Figure 10: Temperature anomaly maps showing difference of the average value on each date for simulated (right) and corrected satellite surface temperature (atmospheric correction and adjustment with bulk measurements, left) in 2017. The 12/05 model map which corresponds to the horizontally uniform initial conditions of the model, does not show any heterogeneity. Date format is day/month.

\section{Discussion}

Hydrodynamic modelling has seldom been applied to reservoirs with considerable water level fluctuations corresponding to wet and dry seasons in a semi-arid climate (Ma et al. 2008). In this section the performance of the hydrodynamic model, the agreement between satellite and measured temperatures and the temperature spatial distribution in model and satellite maps are discussed.

\section{Model simulations and in situ measurements}

Reproduction of the water level fluctuations with a satellite reconstructed bathymetry At Karaoun Reservoir, the Delft3D-Flow model simulated the water level drawdown from July 01 to November 212012 and from May 12 to September 18 2017. The RMSEs were of $0.2 \mathrm{~m}$ for a $15 \mathrm{~m}$ decrease in $2012(n=33)$ and $0.1 \mathrm{~m}$ for an $8 \mathrm{~m}$ decrease in $2017(n=130)$, i.e. below $2 \%$ absolute error. The discrepancy during fall 2012 can be attributed to the more imprecise bathymetry in the lower part of the reservoir (Appendix). Applying the one-dimensional vertical (1DV) model DYRESM to Karaoun Reservoir, a RMSE around $0.5 \mathrm{~m}$ for a level variation of 25 $\mathrm{m}$ (2\% error) was obtained for the entire years 2010, 2011 and 2012 (Fadel et al. 2017). Applying another 1DV model, the General Lake Model (GLM) to Serra Azul Reservoir in Brazil from 2011 to 2016, a RMSE of $0.74 \mathrm{~m}(n=1997)$ for a level variation of $22 \mathrm{~m}(3 \%$ error $)$ was obtained (Soares et al. 2019). This demonstrates that the Delft3D-Flow model represents very well the large water level drawdown in reservoirs, here in a Mediterranean climate context. This is all the more important since large fluctuations in the water level strongly influence the thermal regime of reservoirs. These include changes in mixing and stratification (Soares et al. 2019), and consequently in the water quality in reservoirs (Wang et al. 2012). Deep withdrawals at Sejnan Reservoir (Tunisia) weakened the thermal stratification, increased the thickness of the metalimnion and intensified the hypoxia (Zouabi-Aloui et al. 2015). A decrease in the water level 
by $11 \mathrm{~m}$ between July and October at Arancio reservoir (Italy, maximum depth of $30 \mathrm{~m}$ ) caused the elimination of the thermocline in mid-summer (Naselli-Flores and Barone, 2003). Therefore, obtaining a good model representation of the water level is crucial to accurately capture the thermal behavior of reservoirs.

\section{Reproduction of water thermal stratification with limited calibration}

The 3D hydrodynamic model successfully reproduced the thermal regime exhibited by high frequency measurements ( $30 \mathrm{~min}$ ) at Karaoun Reservoir. The model was able to capture the strong thermal stratification in summer, a period of great interest since it features intense blooms of cyanobacteria. During this period in 2012 and 2017, wind speeds were low and did not exceed $5 \mathrm{~m} \mathrm{~s}^{-1}$ (Fig. 3) thus allowing the persistence of the thermal stratification. As withdrawals occur 11 $\mathrm{m}$ above the reservoir bottom, they did not erode the thermal stratification. Temperatures were overestimated in the epilimnion for 2012 and 2017 (Fig. 4), as was already observed for 2012 with the one-dimensional model DYRESM (Fadel et al. 2017). Overall, the model simulated well water temperature at different depths during these stratified conditions.

In the horizontal dimension, simulated temperatures are more homogeneous than measurements (Fig. 4c-f). The model temperature overestimation in July, in surface layers (Fig. 6a-c), may be due to temporary meteorological differences between the reservoir and the 40-km distant weather station. The measured variability of subsurface temperature is higher at point $\mathrm{S}_{\mathrm{D}}$ than at points $\mathrm{S}_{M}$ and $\mathrm{S}_{\mathrm{R}}$, whereas it is more spatially homogeneous in the model (Fig.6a-c). Part of measured variability can be explained by the low accuracy of the temperature sensors used in 2017 (around $0.5^{\circ} \mathrm{C}$ ). But the most probable reason for the discrepancy is likely to be the horizontally uniform meteorological forcing in the model. An alternative would be to use a weather reanalysis like the ERA interim dataset of the European Centre for Medium-Range Weather Forecasts, but its resolution ( $80 \mathrm{~km}$ with a $12 \mathrm{~h}$ time step) is not sufficient compared with, for example, COSMO-1 reanalysis (1.1 km and hourly) used for Lake Geneva by Baracchini et al. (2020).

Even if the horizontal surface temperature heterogeneity is not fully represented, the errors over the vertical profiles, at each measurement site are rather low. RMSEs ranged between 0.5 and 1.1 ${ }^{\circ} \mathrm{C}$ in the epilimnion $(0.2-7 \mathrm{~m})$ and between 0.5 and $1.9^{\circ} \mathrm{C}$ in the metalimnion $(10-16 \mathrm{~m})$. These values are comparable to the results of other 3D hydrodynamic models, e.g., 0.6 to $3.9^{\circ} \mathrm{C}$ for surface temperatures and 0.9 to $5.3{ }^{\circ} \mathrm{C}$ for bottom temperatures in Alqueva reservoir, Portugal, with the RMA10 model (Lindim et al. 2011). The largest temperature deviations occur at the surface and at the thermocline (Table 1 and Fig. 5). They may be attributed to the constant calibrated value for the Secchi depth, and may not be representative of periods of low transparency during phytoplankton blooms. The Secchi depth calibration is a compromise considered to yield acceptable results over the whole epilimnion. The temperature discrepancies are comparable to other results obtained with the same model, in Lake Constance (Wahl and Peeters, 2014) and in Nam Theun Reservoir, Laos (Chanudet et al. 2012). Our results were obtained with limited calibration and without local weather data, which shows that three-dimensional hydrodynamic models need not be reserved to lakes with abundant model input and calibration data.

\section{Landsat 8 water surface temperature}

At Karaoun Reservoir, satellite surface temperatures after atmospheric correction with the singlechannel algorithm (Jiménez-Muñoz et al. 2014) match well with measurements (Fig. 8). This shows that the algorithm is reliable for deriving surface temperature. The underestimate by around 
$2{ }^{\circ} \mathrm{C}$ on August 162017 may come from an inaccurate water content that likely affected the atmospheric correction. The values of the statistical indicators are comparable with those found in other studies. In Karaoun Reservoir, the RMSE of $0.6{ }^{\circ} \mathrm{C}(n=21)$ is considered acceptable compared with $1.2^{\circ} \mathrm{C}(n=27)$ for Embalse del Rio Tercero reservoir, Argentina (Lamaro et al. 2013) and with $1.7^{\circ} \mathrm{C}(n=14)$ for Bimont and Bariousses Reservoirs, France (Simon et al. 2014). The single-channel algorithm provides valuable additional data when in situ measurements are not available, especially in regions where data are scarce.

Among the error sources in surface temperature retrieval, the main one is likely to be the difference between bulk and skin temperature (Prats et al. 2018). At Karaoun Reservoir, bulk temperature was measured at $20 \mathrm{~cm}$ below the surface. In the literature, bulk temperatures are usually measured over depths ranging from a few centimeters to several meters, depending upon the depth of the surface mixed layer (Schmidt et al. 2018). At least during morning overpasses, bulk water temperatures can be considered representative of skin water temperatures (Schneider and Mauser 1996; Huang et al. 2017). In this work, in order to obtain a proxy of bulk temperatures, skin temperatures were adjusted with bulk measurements with a linear regression, for a more representative comparison with model results.

\section{Spatial distribution of surface temperature}

The horizontal distribution of satellite temperatures in Karaoun Reservoir was shown to be partly reproduced by the model. Both model and satellite maps displayed relatively low horizontal heterogeneities, typically $<0.5{ }^{\circ} \mathrm{C}$. In satellite maps at Karaoun Reservoir, temperatures are often slightly higher in the littoral zone. All satellite images correspond to periods in summer and autumn when the relatively low observed wind speeds $\left(<4 \mathrm{~m} \mathrm{~s}^{-1}\right)$ cannot induce internal waves nor upwellings, nor the subsequent surface temperature gradients. The same way, the low measured inflows in the dry season cannot modify surface temperature close to the river mouth. Lower heterogeneity in simulated temperature maps than in satellite maps has been observed by Allan et al. (2016) who compared 3D ELCOM simulations to Landsat 7 images on Lake Rotoehu in New Zealand. The authors interpreted the differences as partly due to the quality of the meteorological forcing, especially air temperature and wind speed and direction. In Karaoun Reservoir, located in a relatively narrow valley, the low simulated heterogeneity probably originates also from the horizontally uniform meteorological forcing from the distant weather station.

\section{Conclusion}

The thermal functioning of lakes and reservoirs has a significant impact on water quality and ecological processes. In reservoirs, hydrodynamics presents specific patterns related to advection processes. In Mediterranean regions, there may also be large variability of the hydrological regime, which results in high water level variation and concomitant effects on hydrodynamics. In this paper, we assessed whether satellite imagery combined with three-dimensional modelling can provide reliable information about the thermal regime of poorly monitored reservoirs. The model showed its ability to simulate the thermal regime of a semi-arid reservoir with a limited data set for initial conditions and hydrological and meteorological forcing and for the satellitereconstructed bathymetry. Simulated, measured and satellite temperatures were nevertheless in good agreement. Our results demonstrate the potential of coupling in situ, satellite and modelling results for an operational survey of lakes and reservoirs worldwide, including those that are poorly monitored. For validating 3D hydrodynamic models, satellite temperatures constitute a valuable 
source of data complementary to in situ point measurements, which may be often sparse or challenging to acquire. This validation is mandatory before performing biogeochemical simulations and achieving a comprehensive overview of ecosystem biogeochemical processes. The combination of limited in situ monitoring, remote sensing and modelling, currently principally applied to coastal and ocean dynamics at large space and time scales, could be applied, after the validation of the approach, to longer periods to examine interannual variability and long-term trends. It also paves the way for prospective simulations of the thermal and hydrodynamic processes driving lake and reservoir ecosystems under climate change forcing.

\section{Acknowledgements}

The authors thank the Litani River Authority for providing hydrological data and the Lebanese Agricultural Research Institute for providing meteorological data.

\section{Disclosure statement}

No potential conflict of interest was reported by the author(s).

\section{Funding}

This work was supported by the National Council for Scientific Research of Lebanon (Conseil National de la Recherche Scientifique - Liban [CNRS-L]): [Grant Number GRP 2765], Ecole des Ponts ParisTech, and the Hubert Curien CEDRE program (42486XK). The authors acknowledge the CNRS-L for granting a doctoral fellowship to NS. 


\section{Supplementary data: Bathymetry construction}

The water contours used for the construction of the bathymetry of Karaoun Reservoir were extracted from three Landsat images at the maximum water level and at $13.5 \mathrm{~m}$ and $17.44 \mathrm{~m}$ below the maximum water level, corresponding respectively to $859,845.5$ and $842 \mathrm{~m}$ above sea level (Fig. S1). It was necessary to complete this information to describe the lowest part of the reservoir. A straight line was added, linking the river inlet on the lowest contour and the deepest point of the reservoir ( $60 \mathrm{~m}$ below the maximum level). The contours and this line were interpolated to form the full bathymetry.
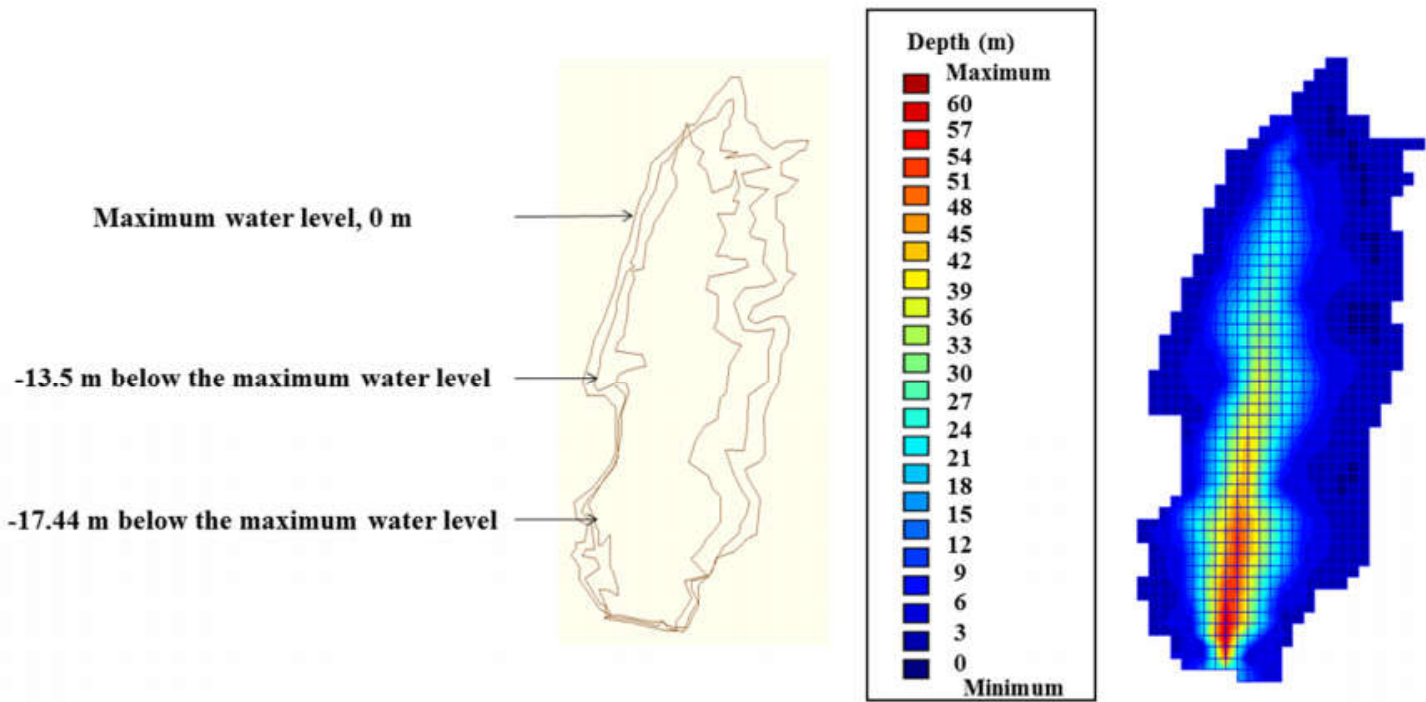

Karaoun Reservoir contours

Karaoun Reservoir bathymetry

Figure S1: Water contours and bathymetry of Karaoun Reservoir. 


\section{References}

Adrian R, O'Reilly CM, Zagarese H, Baines SB, Hessen DO, Keller W, Livingstone DM, Sommaruga R, Straile D, Van Donk E, Weyhenmeyer GA. 2009. Lakes as sentinels of climate change. Limnol Oceanogr. 54:2283-2297.

Allan MG, Hamilton DP, Trolle D, Muraoka K, McBride C. 2016. Spatial heterogeneity in geothermally-influenced lakes derived from atmospherically corrected Landsat thermal imagery and three-dimensional hydrodynamic modelling. Int J Appl Earth Obs. 50:106-116.

Babbar-Sebens M, Li L, Song K, Xie S. 2013. On the Use of Landsat-5 TM Satellite for Assimilating Water Temperature Observations in 3D Hydrodynamic Model of Small Inland Reservoir in Midwestern US. Adv Remote Sens. 2:214-227.

Baracchini T, Chu PY, Sukys J, Lieberherr G, Wunderle S, Wüest AJ, Bouffard D. 2020. Data assimilation of in situ and satellite remote sensing data to 3D hydrodynamic lake models: a case study using Delft3D-FLOW v4. 03 and OpenDA v2. 4. Geosci Model Dev. 13:1267-1284.

Chanudet V, Fabre V, van der Kaaij T. 2012. Application of a three-dimensional hydrodynamic model to the Nam Theun 2 Reservoir (Lao PDR). J Great Lakes Res. 38:260-269.

Crosman ET, Horel JD. 2009. MODIS-derived surface temperature of the Great Salt Lake. Remote Sens Environ. 113:73-81.

Curtarelli MP, Alcântara EH, Rennó CD, Stech JL. 2014. Physical changes within a large tropical hydroelectric reservoir induced by wintertime cold front activity. Hydrol Earth Syst Sci. 18:3079-93.

Cyr H. 2017. Winds and the distribution of nearshore phytoplankton in a stratified lake. Water Res. 122:114-127.

Dee DP, Uppala SM, Simmons AJ, Berrisford P, Poli P, Kobayashi S, Andrae U, Balmaseda MA, Balsamo G, Bauer DP, Bechtold P. 2011. The ERA-Interim reanalysis: Configuration and performance of the data assimilation system. Q J Roy Meteor Soc. 137:553-597.

Delpla I, Jung AV, Baures E, Clement M, Thomas O. 2009. Impacts of climate change on surface water quality in relation to drinking water production. Environ Int. 35:1225-1233.

Deltares. 2013. Delft3D-FLOW user manual. The Netherlands: Delft.

Deutsch ES, Alameddine I. 2019. Hindcasting eutrophication and changes in temperature and storage volume in a semi-arid reservoir: a multi-decadal Landsat-based assessment. Environ Monit Assess. 191:41.

Fadel A, Atoui A, Lemaire BJ, Vinçon-Leite B, Slim K. 2015. Environmental factors associated with phytoplankton succession in a Mediterranean reservoir with a highly fluctuating water level. Environ Monit Assess. 187:633.

Fadel A, Lemaire BJ, Atoui A, Vinçon-Leite B, Amacha N, Slim K, Tassin B. 2014. First assessment of the ecological status of Karaoun Reservoir, Lebanon. Lakes Reserv Res Manag. 19:142-157.

Fadel A, Lemaire BJ, Vinçon-Leite B, Atoui A, Slim K, Tassin B. 2017. On the successful use of a simplified model to simulate the succession of toxic cyanobacteria in a hypereutrophic reservoir with a highly fluctuating water level. Environ Sci Pollut Res. 24:20934-20948.

Fadel A, Sharaf N, Siblini M, Slim K, Kobaissi A. 2019. A simple modelling approach to simulate the effect of different climate scenarios on toxic cyanobacterial bloom in a eutrophic reservoir. Ecohydrol Hydrobiol. 19:359-369.

Fadel A, Slim K. 2018. Evaluation of the Physicochemical and Environmental Status of Qaraaoun Reservoir: The Litani River, Lebanon: An Assessment and Current Challenges. Springer. 71-86.

Huang Y, Liu H, Hinkel K, Yu B, Beck R, Wu J. 2017. Analysis of thermal structure of arctic lakes at local and regional scales using in situ and multidate Landsat-8 data. Water Resour Res. 53:9642-9658. 
Javaheri A, Babbar-Sebens M, Miller RN. 2016. From skin to bulk: An adjustment technique for assimilation of satellite-derived temperature observations in numerical models of small inland water bodies. Adv Water Resour. 92:284-298.

Jiménez-Muñoz JC, Sobrino JA, Skoković D, Mattar C, Cristóbal J. 2014. Land surface temperature retrieval methods from Landsat-8 thermal infrared sensor data. IEEE Geosci. Remote Sens Lett. 11:1840-1843.

Lamaro AA, Marinelarena A, Torrusio SE, Sala SE. 2013. Water surface temperature estimation from Landsat 7 ETM+ thermal infrared data using the generalized single-channel method: Case study of Embalse del Río Tercero (Córdoba, Argentina). Adv Space Res. 51:492-500.

Li Y, Zhang Q, Zhang L, Tan Z, Yao J. 2017. Investigation of water temperature variations and sensitivities in a large floodplain lake system (Poyang Lake, China) using a hydrodynamic model. Remote Sens. 9:1231.

Lindim C, Pinho JL, Vieira JMP. 2011. Analysis of spatial and temporal patterns in a large reservoir using water quality and hydrodynamic modeling. Ecol Model. 222:2485-2494.

Livingstone DM, Dokulil MT. 2001. Eighty years of spatially coherent Austrian lake surface temperatures and their relationship to regional air temperature and the North Atlantic Oscillation. Limnol Oceanogr. 46:1220-1227.

Liu M, Zhang Y, Shi K, Zhu G, Wu Z, Liu M, Zhang Y. 2019. Thermal stratification dynamics in a large and deep subtropical reservoir revealed by high-frequency buoy data. Sci Total Environ. 651:614-624.

Ma S, Kassinos SC, Fatta Kassinos D, Akylas E. 2008. Effects of selective water withdrawal schemes on thermal stratification in Kouris Dam in Cyprus. Lakes Reserv Res Manag. 13:51-61.

Makarigakis AK, Jimenez-Cisneros BE. 2019. UNESCO's contribution to face global water challenges. Water. $11: 388$

Naselli-Flores L, Barone R. 2003. Steady-state assemblages in a Mediterranean hypertrophic reservoir. The role of Microcystis ecomorphological variability in maintaining an apparent equilibrium. Hydrobiologia. 502:133-143.

Peeters F, Livingstone DM., Goudsmit GH, Kipfer R, Forster R. 2002. Modeling 50 years of historical temperature profiles in a large central European lake. Limnol. Oceanogr. 47:186-197.

Prats J, Reynaud N, Rebière D, Peroux T, Tormos T, Danis PA. 2018. LakeSST: Lake skin surface temperature in French inland water bodies for 1999-2016 from Landsat archives. Earth Syst Sci Data. 10:727-743.

Reinart A, Reinhold M. 2008. Mapping surface temperature in large lakes with MODIS data. Remote Sens Environ. 112:603-611.

Schmidt SR, Gerten D, Hintze T, Lischeid G, Livingstone DM, Adrian R. 2018. Temporal and spatial scales of water temperature variability as an indicator for mixing in a polymictic lake. Inland Waters. 8:82-95.

Schneider K, Mauser W. 1996. Processing and accuracy of Landsat Thematic Mapper data for lake surface temperature measurement. Int J Remote Sens. 17:2027-2041.

Sharaf N, Bresciani M, Giardino C, Faour G, Slim K, Fadel A. 2019a. Using Landsat and in situ data to map turbidity as a proxy of cyanobacteria in a hypereutrophic Mediterranean reservoir. Ecol Inform. 50:197-206.

Sharaf N, Fadel A, Bresciani M, Giardino C, Lemaire BJ, Slim K, Faour G, Vinçon-Leite B. 2019b. Lake surface temperature retrieval from Landsat-8 and retrospective analysis in Karaoun Reservoir, Lebanon. J Appl Remote Sens. 13:044505.

Sharma S, Jackson DA, Minns CK, Shuter BJ. 2007. Will northern fish populations be in hot water because of climate change?. Glob Change Biol. 13:2052-2064. 
Simon RN, Tormos T, Danis PA. 2014. Retrieving water surface temperature from archive LANDSAT thermal infrared data: Application of the mono-channel atmospheric correction algorithm over two freshwater reservoirs. Int J Appl Earth Obs. 30:247-250.

Soares LMV, Silva TFDG, Vinçon-Leite B, Eleutério JC, Lima LCD, Nascimento NDO. 2019. Modelling drought impacts on the hydrodynamics of a tropical water supply reservoir. Inland Waters. 9:422-437.

Soulignac F, Anneville O, Bouffard D, Chanudet V, Dambrine E, Guénand Y, Harmel T, Ibelings BW, Trevisan D, Uittenbogaard R, Danis PA. 2019. Contribution of 3D coupled hydrodynamic-ecological modeling to assess the representativeness of a sampling protocol for lake water quality assessment. Knowl Manag Aquat Ecosyst. 420 :42.

Soulignac F, Danis PA, Bouffard D, Chanudet V, Dambrine E, Guénand Y, Harmel T, Ibelings BW, Trevisan D, Uittenbogaard R, Anneville O. 2018. Using 3D modeling and remote sensing capabilities for a better understanding of spatio-temporal heterogeneities of phytoplankton abundance in large lakes. J Great Lakes Res. 44:756-764.

Soulignac F, Vinçon-Leite B, Lemaire BJ, Martins JRS, Bonhomme C, Dubois P, Mezemate Y, Tchiguirinskaia I, Schertzer D, Tassin B. 2017. Performance assessment of a 3D hydrodynamic model using high temporal resolution measurements in a shallow urban lake. Environ Model Assess. 22:309-322.

Vinçon-Leite B, Lemaire BJ, Khac VT, Tassin B. 2014. Longterm temperature evolution in a deep sub-alpine lake, Lake Bourget, France: How a one-dimensional model improves its trend assessment. Hydrobiologia. 731:49-64.

Wahl B, Peeters F. 2014. Effect of climatic changes on stratification and deep-water renewal in Lake Constance assessed by sensitivity studies with a 3D hydrodynamic model. Limnol Oceanogr. 59:1035-1052.

Wang S, Qian X, Han BP, Luo LC, Hamilton DP. 2012. Effects of local climate and hydrological conditions on the thermal regime of a reservoir at Tropic of Cancer, in southern China. Water Res. 46:2591-2604.

Watanabe F, Alcantara E., Rodrigues T, Rotta L, Bernardo N, Imai N. 2018. Remote sensing of the chlorophyll-a based on OLI/Landsat- 8 and MSI/Sentinel-2A (Barra Bonita reservoir, Brazil). Anais da Academia Brasileira de Ciências. 90:1987-2000.

Wüest A, Lorke, A. 2003. Small-scale hydrodynamics in lakes. Annu Rev Fluid Mech. 35:373-412.

Yang Y, Colom W, Pierson D, Pettersson K. 2016. Water column stability and summer phytoplankton dynamics in a temperate lake (Lake Erken, Sweden). Inland Waters. 6:499-508.

Ye X, Chu PY, Anderson EJ, Huang C, Lang GA, Xue P. 2020. Improved thermal structure simulation and optimized sampling strategy for Lake Erie using a data assimilative model. J Great Lakes Res. 46:144-158.

Zouabi-Aloui B, Adelana SM, Gueddari M. 2015. Effects of selective withdrawal on hydrodynamics and water quality of a thermally stratified reservoir in the southern side of the Mediterranean Sea: a simulation approach. Environ Monit Assess. 187:292. 